\title{
Mechanisms of Action by Antimicrobial Agents: A Review
}

\author{
Som Prabh Singh ${ }^{1}$ | Ammar Qureshi ${ }^{2}$ | Wail Hassan ${ }^{1}$
}

${ }^{1}$ University of Missouri - Kansas City, Kansas City, Missouri, United States

${ }^{2}$ University of Kansas, Lawrence, Kansas, United States

Correspondence

Som Prabh Singh

Email: somsingh2023@gmail.com

Publication Date

January 04, 2021

MJM 2021 (19) 4

\section{\$. McGill \\ Journal of Medicine}

www.mjmmed.com

\section{c) (1) (8)}

This work is licensed under a Creative Commons BY-NC-SA 4.0 International License.

\section{1 | INTRODUCTION}

The explosive growth in the use of antimicrobial therapy has provided a degree of control on microbial-related diseases in humans. However, microbial resistance to antibiotics also developed over time, resulting in an arms-race for developing newer agents against these more resistant strains. As a result, practicing clinicians have an obligation to remain informed on modern antimicrobial agents and to understand their core mechanisms of action. Bacteria and fungi differ in cellular composition, but the levels at which these microbes can be altered are similar: protein synthesis, nucleic acid syn-

\begin{abstract}
Microorganisms and their associated conditions comprise some of the world's leading causes of death and have the potential to cause a significant effect on human activities during pandemic states. Despite such significance in the healthcare field, attention and funding directed towards microbiological research lags behind those given to cancer and cardiovascular disease. In the current SARS-CoV-2 pandemic, the need of healthcare providers to remain knowledgeable on antimicrobial therapy for their patients is greater than ever before. The scope of this review is to provide clinicians a semi-comprehensive, up-to-date understanding of the mechanisms of action among antimicrobial agents as well as key distinctions in clinical manifestations of pathogens.

- KEYWORDS

Antimicrobial Activity, Mechanism of Action, Antiviral, Antifungal, Antibiotic
\end{abstract}

thesis, cell wall, and cell membrane. Viruses, on the other hand, are different structurally as they do not contain a cell membrane or cell wall. (1) The aim of this review is to provide a categorical overview of antimicrobial agent mechanisms and brief clinical manifestations.

\section{2 | METHODS}

An electronic database search was performed on MEDLINE (PubMed) using the following criteria: ("antimicrobial agents" [All Fields]) OR ("penicillin" [All Fields] OR ("sulfonamide" [All Fields]) OR ("protein synthesis 
antibacterial "[All Fields]) OR ("antifungal" [All Fields]) OR ("antiviral"[All Fields]) AND "access"[All Fields] AND "outcomes"[All Fields]). The results were narrowed down to 810 publications after filtering for free, fulltext, and 88 publications were selected by the reviewers (SPS and AQ) for analysis. Afterwards, the reviewers excluded 18 duplicate publications, resulting in 70 publications for the final analysis. Additionally, two medical textbooks were used to yield relevant clinical information for medical students. $(1,63)$

\section{3 | ANTIBACTERIAL AGENTS}

\subsection{Agents Acting Through Cell Wall Synthesis}

While the organic synthesis and structure of the cell wall is different between bacteria and fungi, its presence helps limit changes in the internal osmotic pressure of both microbes. $(1,2)$ Since the cell wall is not present in mammalian cells, this structure is a key antimicrobial target that minimizes impact on normal host tissue. (1)

\subsection{1 | Beta-Lactam Containing Antimicrobials}

Penicillin is a group of antimicrobials that resembles a structural analogue of $\mathrm{D}$-alanyl-D-alanine in most cases. (2) This analogue competes for the D-alanyl-D-alanine transpeptidase, also known as the penicillin-binding protein, which joins layers of peptidoglycan on the cell wall. By inactivating peptidoglycan synthesis, penicillin creates higher internal osmotic pressure that leads to cell lysis. (2) Additionally, penicillin is a ß-lactam drug because it contains an eponymous ß-lactam ring essential for its function. When the ß-lactam ring is destroyed, penicillin loses its analogous quality and no longer competes for transpeptidase. (4) Additionally, patients who are allergic to penicillin may resort to using alternative ß-lactam drugs such as cephalosporins and carbapenems. (3) This group of molecules are structurally different from penicillin but are functionally similar and have a broad-range spectrum of bacterial coverage. (1-7) Bac- terial resistance to $ß$-lactam-containing agents develops during endogenous production of penicillinases/ßlactamases by bacterial strains. To protect the ß-lactam ring from degradation by these penicillinases, a large molecular side chain structure may be added. (2) This addition led to the creation of penicillinase-resistant penicillin (e.g. dicloxacillin, nafcillin, oxacillin). They have a smaller spectrum of activity, with targeted efficacy against Staphylococcus aureus. (1) Monobactams (e.g. aztreonam) comprise another ß-lactam drug class that affect transpeptidation and are primarily used against aerobic Gram negative bacteria due to their molecular structure. (2-6)

\subsection{2 | Vancomycin}

While ß-lactam drugs specifically target the transpeptidase, preceding enzymatic steps in peptidoglycan synthesis can also serve as antibacterial targets. For example, vancomycin binds directly to D-alanyl-D-alanine transpeptidase to inhibit cross-linking. (63) Vancomycin thus prevents peptidoglycan synthesis without being susceptible to ß-lactamases. (1) Vancomycin is clinically used against methicillin-resistant Staphylococcus aureus (MRSA). Noteworthy side effects of vancomycin include nephrotoxicity, ototoxicity, and thrombophlebitis (similar effects are also found with aminoglycosides). (1) This review search yielded a case study of a patient who presented with "red man syndrome" due to vancomycin's ability to directly bind to mast cells causing them to release histamine, promoting vasodilation. (69)

\subsection{3 | Bacitracin and Cycloserine}

Bacitracin is an antibacterial agent that inhibits transport of peptidoglycan subunits from the cytoplasm to the cell wall by inactivating its phospholipid carrier. (7) In contrast, cycloserine inhibits synthesis of D-alanyl-Dalanine inside the cell. (7) Comparatively, the literature on cycloserine was scarce compared to other agents in this review, which could also imply that cycloserine is used less often in clinical settings than other agents. 


\section{2 | Agents Acting Through Microbial Protein Synthesis}

\subsection{1 | Aminoglycosides}

Aminoglycosides are a broad-spectrum bactericidal class of antibiotics that can be semi-synthetic or naturally derived from Gram positive actinomycetes. (13) They exert their antibacterial effects by inhibiting the prokaryotic ribosomal initiation complex, which results in misreading of messenger RNA (mRNA). (1) Oxygendependent active electron transport is required for aminoglycoside uptake into cells, explaining their lack of activity against anaerobic bacteria. (13) Streptomycin is an aminoglycoside that irreversibly binds to the A-site $30 \mathrm{~S}$ ribosomal subunit of the initiation complex in bacteria. $(1,15)$ Furthermore, streptomycin can be nephrotoxic as well as ototoxic due to degeneration of sensory cells in the basal cochlea. $(15,16)$ While streptomycin is no longer used as widely in Canada or the United States anymore, it holds historical importance because it was the first aminoglycosides discovered for clinical use, specifically against tuberculosis, bubonic plague, and brucellosis. (1) Other aminoglycosides include gentamicin (used against various Gram-negative rods such as Pseudomonas aeruginosa), amikacin (used against gentamicin-resistant organisms), and neomycin (used against various enteric gram negative rods). (13) Aminoglycosides usually are not given orally as they are poorly absorbed in the GI tract. $(1,13)$ However, oral neomycin is given in preoperative bowel preparation. (1)

\subsection{2 | Tetracyclines}

Tetracyclines are bacteriostatic antibiotics that, like aminoglycosides, inhibit microbial protein synthesis by binding to the $30 \mathrm{~S}$ ribosomal subunit. (63) However, rather than binding irreversibly to the A-site $30 \mathrm{~S}$ ribosomal subunit of the bacterial initiation complex, tetracyclines reversibly inhibit the binding of transfer RNA (tRNA) to the acceptor site, hindering polypeptide growth. Tetracyclines also chelate calcium and iron, and hence should not be taken simultaneously with supplement forms of calcium and iron to avoid micronutri- ent deficiencies. In addition, tetracycline is contraindicated in infants and in pregnancy due to tooth discoloration through calcium-chelation. (17) A newer class of antibiotics called tigecyclines are structurally similar to tetracyclines and also bind to the 30s ribosomal subunit. (1) Clinically, tigecycline are used to treat complicated intra-abdominal infections and skin/soft tissue infections, with notably activity against MRSA. (59)

\subsection{3 | Chloramphenicol}

Chloramphenicol is a broad-spectrum antibiotic that blocks peptidyltransferase at the $50 \mathrm{~S}$ ribosome subunit to prevent protein synthesis. This class of antimicrobials is bacteriostatic against many bacteria responsible for ocular infections. The literature notes bactericidal activity against the meningitis-causing microbes Haemophilus influenzae, Neisseria meningitidis, and Streptococcus pneumoniae. (63) Chloramphenicol toxicity comes in two forms: 1) a predictable, reversible, dosedependent bone marrow suppression that can start soon after administration; 2) an unpredictable, rare, and disastrous irreversible agranulocytosis, which generally occurs during prolonged therapy.18 Metabolically, chloramphenicol is detoxified through UDP-glucuronyl transferase.1,18 Toxic chloramphenicol serum concentration may result in gray-colored skin and cyanosis in infants, which has been documented as infantile "graybaby" syndrome. (71)

\subsection{4 | Macrolides and Clindamycin}

Macrolides interact through the $50 \mathrm{~S}$ ribosome subunit of bacteria via blocking translocation of tRNA. (63) Azithromycin is a macrolide used to treat respiratory tract infections and Chlamydia-induced genital tract infections. (18) Clarithromycin has a similar spectrum and treats Helicobacter infections such as peptic ulcer disease. Side-effects include arrhythmia from QTprolongation and cholestatic hepatitis. (63) Both clarithromycin and erythromycin were shown in a study to inhibit cytochrome P-450. (19)

Clindamycin also inhibits translocation of tRNA on 
the 50 ribosome subunit of bacteria. $(1,63)$ It is used to treat anaerobic infections above the diaphragm such as aspiration pneumonia and lung abscesses. (1,19) A major adverse effect of clindamycin is the overgrowth of a drug-resistant strain of Clostridium difficile in the gastrointestinal tract, which can produce an exotoxin leading to pseudomembranous colitis. (19)

\subsection{5 | Oxazolidinones}

Oxazolidinones inhibit the formation of the initiation complex on the 50s ribosomal subunit. These agents are particularly useful against MRSA, vancomycin-resistant Enterococci, and penicillin-resistant Streptococcus pneumoniae. $(21,63)$ Adverse effects include serotonin syndrome and tyramine-induced hypertensive crisis, since some oxazolidinones such as linezolid are monoamine oxidase inhibitors. (21)

\section{3 | Agents Acting Through Nucleic Acid Synthesis}

\subsection{1 | Sulfonamides and Trimethoprim}

Sulfonamides competitively inhibit p-aminobenzoic acid (PABA), an early precursor of tetrahydrofolic acid, which is required for nucleic acid synthesis of all nitrogenous bases except cytosine. (22) By inhibiting PABA, sulfonamides render the dihydropteroate synthase inactive. $(1,22,63)$ Clinically, sulfonamides are used to treat urinary tract infections caused by Escherichia coli as well as middle ear infections caused by Streptococcus pneumoniae and Haemophilus influenzae. (22) Moreover, it is critical to understand that while nucleic acids are present in both prokaryotes and eukaryotes, mammalian cells do not have PABA-containing precursor enzymes and instead rely on exogenous folic acid to meet their metabolic requirements for nucleic acid synthesis (23), which in theory can limit sulfonamides targeting of mammalian cells. Sulfonamides are commonly used in combination with trimethoprim. (23) Trimethoprim similarly inhibits the production of tetrahydrofolic acid, but its mechanism involves the inhibition of a later enzyme in the pathway, dihydrofolate reductase. $(1,63)$ Thus, sulfonamide and trimethoprim act synergistically. However, as trimethoprim inhibits folic acid synthesis, bone marrow suppression may result, leading to potential megaloblastic anemia. (22)

\subsection{2 | Fluoroquinolones}

Unlike sulfonamides and trimethoprim, which are independent bacteriostatic agents, fluoroquinolones are bactericidal drugs that inhibit DNA gyrase and DNA topioisomerase in bacteria. (26) Fluoroquinolones (e.g. ciprofloxacin, levofloxacin, etc.) can be used to treat urinary tract infections and lower respiratory tract infections caused by Gram negative rods. (1) Side effects of fluoroquinolones include tendonitis and/or tendon rupture in elderly patients. (63) Fluoroquinolones have been contraindicated in children and pregnant women due to potential interference with bone growth, but this has only been reported in animal models. (26-27)

\subsection{3 | Rifamycin}

Rifamycins selectively bind to the $\beta$ subunit of bacterial RNA polymerase, rendering it inactive for mRNA synthesis. (1) Rifampin is specifically useful in the treatment and prophylaxis of Mycobacterium tuberculosis-caused tuberculosis and meningitis, respectively. $(31,63)$ It also aids in the treatment of leprosy by attenuating antimicrobial resistance to dapsone. (31) Patients on rifampin may have harmless reddish orange urine (1) due to the drug's color being distilled by body fluids. Rifampin may also result in hepatotoxicity as it induces cytochrome P450 enzymes; thus it is not recommended for HIV patients. (1) Rifabutin is a rifampin derivative that can be used by HIV patients as it induces cytochrome P-450 enzymes to a lesser degree than rifampin. $(30,31)$ 


\section{4 | Agents That Alter Cell Membranes}

\subsection{1 | Polymyxin and Daptomycin}

Polymyxins such as Polymyxin E proteins disrupt the charge of phospholipids in the bacterial cell membrane.

(32) They are useful against many Gram-negative rods and carbapenemase-producing Enterobacteriaceae. (63) Daptomycin similarly disrupts the cell membranes of gram positive cocci and MRSA through depolarization, but is not effective in the lung due to pulmonary surfactant interfering with its mechanism of action. (32)

\section{ANTIFUNGAL AGENTS}

The fungal cell wall is composed of a solubilized chitin-ß(1,3)- glucan linked by a $ß-(1,6)$-glucan to mannoproteins on the outer surface of the fungal cell wall. (10) ß-glucan is synthesized by a multi-subunit enzyme, 1,3-ß-glucan synthase. (11) Previous literature on this enzyme shows that its inhibition results in physiological cell cycle arrest and hence has become a key target in antifungal therapy through the echinocandin lipopeptide class of antifungal therapy. (10-11)

\section{1 | Agents that Alter the Cell Wall}

Caspofungin is a part of the echinocandins, a lipopeptide drug class that non-competitively inhibits 1,3-ßglucan synthase. It is mainly used against systemic yeast infections, such as disseminated candidiasis and invasive aspergillosis. (11) However, caspofungin has been shown to be ineffective against Cryptococcus or Mucor-induced infections at normal doses. (12) Additionally, another lipopeptide drug, micafungin, has been used for prophylaxis in patients undergoing hematopoietic stem cell transplantation. (70) Anidulafungin is another semisynthetic echinocandin used against invasive esophageal candidiasis in clinical use. (12) Cryptococcus is not susceptible to any of the three semisynthetic echinocandins, but the mechanism of this resistance is not well understood. $(1,11)$

\section{2 | Agents that Alter the Cell Membrane}

Amphotericin B is an antifungal that alters the cell membrane by binding to ergosterol - a compound exclusive to fungi. (1) This results in the formation of ion channels in the fungal cell membrane leading to depolarization of the cell membrane and subsequent cell death. (33) Additionally, amphotericin B is associated with nephrotoxicity and arrythmia, which causes its use by clinicians to be reserved for salvage therapy. Nystatin is a topical antifungal agent that functions similarly to amphotericin and is used for topical Candida infections. (1) Azoles are another class of antifungal cell membrane agents. They work by directly inhibiting ergosterol synthesis. (34) Terbinafine inhibits a squalene epoxidase in ergosterol synthesis and is used in finger and nail fungal infections. $(33,63)$

\subsection{Agents that Alter the Nucleotide and Protein Synthesis}

The scope of fungal nucleic acid inhibitors is smaller. The primary antifungal agent is flucytosine, a nucleoside analogue that can inhibits a thymidine precursor enzyme, resulting in inactive DNA synthesis. $(28,29)$ Griseofulvin and pentamidine are antifungal agents that alter microtubules and DNA synthesis, respectively. (63) Pentamidine is used for treatment and prophylaxis against Pneumocystis jiroveci. (35) Griseofulvin, like terbinafine, is useful in fungal infections of the nailbed. $(35,36)$

\section{5 | ANTIVIRAL AGENTS}

Unlike bacteria and fungi, viruses are acellular structures containing their own set of DNA or RNA and a limited variety of proteins necessary for nucleic acid replication and structural attachment/maintenance. $(1,63)$

\section{1 | Herpesvirus}

The primary herpesviruses of this review are Herpes Simplex Virus type $1 \& 2$ (HSV-1 \& HSV-2), cy- 
tomegalovirus (CMV), Epstein-Barr virus (EBV), and Varicella-Zoster virus (VZV). (58) While HSV-1 is commonly associated with oral cold sores, HSV-2 is usually associated with genital blisters or sores generally below the waist. (42) Patients acutely infected with VZV initially present with febrile symptoms and can develop varicella, while post-latency VZV re-activation commonly causes a dermatomal rash known as shingles. VZV is also associated with vesicular rashes, neuritis, and encephalitis. $(1,42)$ Regarding CMV infection, congenital manifestations such as intracranial calcifications, hydrocephalus, and retinitis are present both with and without symptoms. $(42,63)$ Symptoms in patients infected with CMV include mononucleosis (more common post-neonatally), rash, and malaise. (1) EBV and CMV infections are similar in that both infected children and adults present with mononucleosis-related glandular fever. $(1,58)$

Inhibitors of the herpesviruses can be separated into nucleoside inhibitors and non-nucleoside inhibitors. Acyclovir, ganciclovir, and trifluridine are nucleoside inhibitor analogues that vary in function. Acyclovir is a nucleoside analogue that is preferentially activated by a virus-encoded thymidine kinase primarily found in HSV. (1) Upon phosphorylation of acyclovir, a cellular byproduct, acyclovir triphosphate, inhibits the viral DNA polymerase and subsequent nucleic acid synthesis. Clinically, acyclovir is used in the treatment of genital herpes and is used as a prophylactic agent in patients who are immunocompromised or elderly. (73) Despite its efficacy against active HSV, acyclovir has minimal effect on latent HSV and VZV. (58) Ganciclovir is structurally similar to acyclovir, but is preferentially activated by a CMVencoded phosphokinase to inhibit viral nucleic acid synthesis. $(58,63)$ Cidofovir is another nucleoside analogue that is approved to treat CMV-induced retinitis. (63) In contrast, the non-nucleoside inhibitor of HSV is foscarnet, a pyrophosphate analogue that directly binds to DNA polymerase during pyrophosphate cleavage. This agent is clinically useful against acyclovir-resistant active HSV and CMV infections. $(37,38)$

\section{2 | Hepatitis B and C}

There are multiple types of hepatitis viruses $(A, B, C, D$, $E$ ), but this review will focus on Hepatitis $B$ and C (HBV $\&$ HCV) as they are more likely to cause chronic infection and can also progress into hepatocellular carcinoma (1,52-53); however, it is imperative to know that malaise, jaundice and transaminitis are common manifestations in acute viral hepatitis of any cause. The primary agents acting against chronic HBV infections inhibit viral DNA polymerase, but each of these primary drugs are structurally different analogues, such as entecavir (guanosine analog), adefovir (adenosine monophosphate analogue), and telbivudine (thymidine analogue). The prominent $\mathrm{HCV}$ antiviral agents can be separated into RNA polymerase inhibitors (dasabuvir, sofosbuvir \& simeprevir), nonstructural protein 5a (NS5A) inhibitors (ledipasvir, ombitasvir), and nonstructural protein 5B (NS5B) inhibitors. Their mechanisms of action are beyond the scope of this review. (42-44) Recombinant alpha interferon can also be used against hepatitis B and C infections, but this treatment has fallen out of favor in the past decade due to an unfavorable side-effect profile. (72)

\section{3 | Influenza B and C}

All case studies derived for this review noted the specific strains of Influenza A and B during seasonal epidemics of the flu. Oseltamivir is an oral antiviral medication used to prevent influenza A and B outbreaks. (39,54) Once activated, this pro-drug selectively binds to neuraminidase, an enzyme found on the outer surface of all influenza viruses, to prevent viral release. (1) Other analogues include zanamivir and peramivir. $(1,39,54)$ Baloxavir is a selective inhibitor of influenza cap-dependent endonuclease, and has been shown in clinical trials to reduce viral load more efficiently than oseltamivir. (74). It is currently clinically approved for its medical use in Influenza A infections in the United States. (54) 


\section{4 | Human Immunodeficiency Virus}

Human Immunodeficiency Virus (HIV) is characterized by a unique diploid set of viral RNA. The virus infects and destroys CD4+ T helper cells, thereby weakening the immune system. (1,63) Patients often initially present with a febrile illness resembling mononucleosis, marking the acute phase of the viral infection. (1) The virus then enters the latency phase where it seeds and replicates within latent HIV reservoirs in the body. $(1,63)$ This period can take months to years while the patient is asymptomatic. (1) Eventually, CD4+ serum count decreases causing moderate immunocompromise followed by the Acquired Immunodeficiency Syndrome (AIDS) phase of the infection, characterized by severe opportunistic infections. $(5,57)$

To delay this decline in immune function, multiple agents against HIV are given in combination. The first two major classes of HIV drugs are nucleoside reverse transcriptase inhibitors (NRTIs) and nonnucleoside reverse transcriptase inhibitors (NNRTIs). (57) NRTIs include Abacavir, Didanosine, Emtricitabine, Lamivudine, Stavudine, Tenofovir, and Zidovudine. (63) While each NTRI vary slightly in structure, they all competitively. bind to the HIV reverse transcriptase active site to inhibit viral DNA synthesis, causing chain termination. (1) NNRTIs include Delavirdine, Efavirenz, Etravirine, Nevirapine, and Rilpivirine, all of which inhibit viral DNA synthesis through allosteric inhibition of reverse transcriptase activity. (1,57) Other classes of HIV drugs include protease inhibitors (i.e. lopinavir, ritonavir) and integrase inhibitors (i.e. raltegravir, dolutegravir), which work on their namesake enzymes involved in the systemic growth of the virus. (1)

\section{6 | DISCUSSION}

The core target mechanisms of antimicrobial structure and macromolecule synthesis that were discussed remain classic starting points for the study of novel therapeutic techniques. This review analyzed over 70 academic pieces of literature to provide the most current understanding for healthcare professionals. While most of the antimicrobial agents discussed are likely to be seen in clinical practice, this review does not encompass all agents approved for treatment, nor does it provide new data on the efficacy of these agents. This review suggests that future systematic reviews are needed to provide directions for research on antimicrobial agent mechanisms. Additionally, the timing of this paper coinciding with the ongoing worldwide COVID19 pandemic serves a key role in providing a semi-comprehensive, upto-date understanding of the mechanisms of action of antimicrobial agents in times where many entities are exploring variations and manipulations of these agent mechanisms. $(63,66)$ For example, recent literature suggests that members of the aforementioned fluoroquinolone family of nucleic acid synthesis inhibitors can be used as a form of therapy against COVID-19. The basic mechanisms of action are therefore more pertinent than ever before and open an avenue for discussion of the uses of combination and crossover therapies by these agents.

\section{7 | ACKNOWLEDGEMENTS}

The authors of this review would like to acknowledge Warren E. Levinson, for his comprehensive book: Review of Medical Microbiology and Immunology 14th edition. The authors would also like to thank the University of Missouri - Kansas City School of Medicine for the Sarah Morrison Student Research Award granted to Som Singh.

\section{REFERENCES}

1. Levinson WE. Review of Medical Microbiology and Immunology. 14th ed. McGraw Hill Education; 2016.

2. Scheffers DJ, Pinho MG. Bacterial cell wall synthesis: new insights from localization studies [Internet]. Microbiology and molecular biology reviews. 2005 [cited 2019Dec28]. Available from: https://pubmed.ncbi.nlm.nih.gov/16339737

3. Soares GM, Figueiredo LC, Faveri M, Cortelli SC, Duarte PM, Feres M. Mechanisms of action of systemic antibiotics used in periodontal treatment and mechanisms of bacterial resistance to these drugs [Internet]. Journal of applied oral science: revista FOB. 2012 [cited 2019Dec28]. Available from: 
https://pubmed.ncbi.nlm.nih.gov/22858695/

4. Yocum RR, Rasmussen JR, Strominger JL. The mechanism of action of penicillin. Penicillin acylates the active site of Bacillus stearothermophilus D-alanine carboxypeptidase [Internet]. The Journal of biological chemistry.1980 [cited 2019Dec28]. Available from: https://pubmed.ncbi.nlm.nih.gov/7372662/

5. Barreteau H, Kova? A, Boniface A, Sova M, Gobec S, Blanot D. Cytoplasmic steps of peptidoglycan biosynthesis [Internet]. OUP Academic. Oxford University Press; 2008 [cited 2019Dec28]. Available from: https://academic.oup.com/femsre/article/32/2/168/2683919

6. Lahiri SD, Johnstone MR, Ross PL, McLaughlin RE, Olivier NB, Alm RA. Avibactam and class C -lactamases: mechanism of inhibition, conservation of the binding pocket, and implications for resistance [Internet]. American Society for Microbiology. 2014 [cited 2019Dec28]. Available from: https://www.ncbi.nlm.nih.gov/pmc/articles/PMC4187909/

7. Lambert MP, Neuhaus FC. Mechanism of D-cycloserine action: alanine racemase from Escherichia coli W [Internet]. Journal of bacteriology. 1972 [cited 2019Dec28]. Available from: https://pubmed.ncbi.nlm.nih.gov/4555420/

8. Nguyen R. Bacitracin Topical [Internet]. StatPearls [Internet]. 2020 [cited 2020Dec20]. Available from: https://www.ncbi.nlm.nih.gov/books/NBK536993/

9. Free SJ. Fungal cell wall organization and biosynthesis [Internet]. Adv Genet. 2013 [cited 2020Dec20]. Available from: https://pubmed.ncbi.nlm.nih.gov/23419716/

10. Gow NAR, Latge JP, Munro CA. The Fungal Cell Wall: Structure, Biosynthesis, and Function [Internet]. Microbiol Spectr; 2017 [cited 2019Dec28]. Available from: https://pubmed.ncbi.nlm.nih.gov/28513415/

11. Letscher-Bru V, Herbrecht R. Caspofungin: the first representative of a new antifungal class [Internet]. Journal of Antimicrobial Chemotherapy. 2003 [cited 2019Dec28]. Available from: https://pubmed.ncbi.nlm.nih.gov/12615851/

12. Datry A, Bart-Delabesse E. Caspofungin: mode of action and therapeutic applications [Internet]. Rev Med Interne. 2006 [cited 2019Dec28]. Available from: https://pubmed.ncbi.nlm.nih.gov/16023265/

13. Krause KM, Serio AW, Kane TR, Connolly LE. Aminoglycosides: An Overview [Internet]. Cold Spring Harb Perspect Med. 2016 [cited 2019Dec28]. Available from: https://pubmed.ncbi.nlm.nih.gov/27252397/

14. Rougier F, Claude D, Maurin M, Sedoglavic A, Ducher M, Corvaisier S, Jelliffe R, Maire P. Aminoglycoside nephrotoxicity: modeling, simulation, and control [Internet]. Antimicrob Agents Chemother. 2003 [cited 2019Dec28]. Available from: https://pubmed.ncbi.nlm.nih.gov/12604535/

15. Adeyemo AA, Oluwatosin O, Omotade OO. Study of streptomycin-induced ototoxicity: protocol for a longitudinal study [Internet]. Springerplus 2016 [cited 2019Dec28]. Available from: https://pubmed.ncbi.nlm.nih.gov/27386243/

16. Luzzatto L, Apirion D, Schlessinger D. Mechanism of action of streptomycin in E. coli: interruption of the ribosome cycle at the initiation of protein synthesis [Internet]. Proc Natl Acad Sci U S A. 1968 [cited 2019Dec28]. Available from: https://www.ncbi.nlm.nih.gov/pmc/articles/PMC225133/

17. Chopra I, Roberts M. Tetracycline antibiotics: mode of action, applications, molecular biology, and epidemiology of bacterial resistance [Internet]. Microbiol Mol Biol Rev. 2001 [cited 2019Dec28]. Available from: https://pubmed.ncbi.nlm.nih.gov/11381101/

18. Allison JL, Hartman RE, Hartman RS, Wolfe AD, Ciak J, Hahn FE. Mode of action of chloramphenicol. VII. Growth and multiplication of Escherichia coli in the presence of chloramphenicol [Internet]. J Bacteriol. 1962 [cited 2019Dec28]. Available from: https://pubmed.ncbi.nlm.nih.gov/13860618/

19. Kanoh S, Rubin BK. Mechanisms of action and clinical application of macrolides as immunomodulatory medications. Clin Microbiol Rev. 2010 [cited 2019Dec28]. Available from: https://www.ncbi.nlm.nih.gov/pmc/articles/PMC2901655/

20. Murphy PB, Le JK. Clindamycin [Internet]. In: StatPearls [Internet]. 2019. cited 2020Dec20]. Available from: https://www.ncbi.nlm.nih.gov/books/NBK519574/

21. Bozdogan B, Appelbaum PC. Oxazolidinones: activity, mode of action, and mechanism of resistanc [Internet]e. Int J Antimicrob Agents. 2004 [cited 2019Dec28]. Available from: https://pubmed.ncbi.nlm.nih.gov/15013035/

22. Henry RJ. THE MODE OF ACTION OF SULFONAMIDES [Internet]. Bacteriol Rev. 1943 [cited 2019Dec28]. Available from: https://pubmed.ncbi.nlm.nih.gov/16350088/

23. Cudmore J, Seftel M, Sisler J, Zarychanski R. Methotrexate and trimethoprim-sulfamethoxazole: toxicity from this combination continues to occur [Internet]. Can Fam Physician. 2014 [cited 2019Dec28]. Available from: https://www.ncbi.nlm.nih.gov/pmc/articles/PMC3994806/

24. Kurien G, Jamil RT, Preuss CV. Dapsone In: StatPearls [Internet]. 2019 [cited 2019Dec28]. Available from: https://www.ncbi.nlm.nih.gov/books/NBK470552/

25. Wozel G, Blasum C. Dapsone in dermatology and beyond [Internet]. Arch Dermatol Res. 2014 [cited 2019Dec28]. Available from: https://pubmed.ncbi.nlm.nih.gov/24310318/

26. Hooper DC. Mechanisms of action of antimicrobials: focus on fluoroquinolones [Internet]. Clin Infect Dis. 2001 [cited 2019Dec28]. Available from: https://pubmed.ncbi.nlm.nih.gov/11249823/

27. Aldred KJ, Kerns RJ, Osheroff N. Mechanism of quinolone action and resistance [Internet]. Biochemistry. 2014 [cited 2019Dec28]. Available from: https://pubmed.ncbi.nlm.nih.gov/24576155/

28. Loyse A, Dromer F, Day J, Lortholary O, Harrison TS. Flucytosine and cryptococcosis: time to urgently address the worldwide accessibility of a 50-year-old antifungal [Internet]. J An- 
timicrob Chemother. 2013 [cited 2019Dec28]. Available from: https://www.ncbi.nlm.nih.gov/pmc/articles/PMC3797641/

29. Vermes A, Guchelaar HJ, Dankert J. Flucytosine: a review of its pharmacology, clinical indications, pharmacokinetics, toxicity and drug interactions [Internet]. J Antimicrob Chemother. 2000 [cited 2019Dec28]. Available from: https://pubmed.ncbi.nlm.nih.gov/10933638/

30. Saito K, Warrier T, Somersan-Karakaya S, Kaminski L, Mi J, Jiang X, Park S, Shigyo K, Gold B, Roberts J, Weber E, Jacobs WR Jr, Nathan CF. Rifamycin action on RNA polymerase in antibiotic-tolerant Mycobacterium tuberculosis results in differentially detectable populations [Internet]. Proc Natl Acad Sci U S A. 2017 [cited 2019Dec28]. Available from: https://europepmc.org/article/pmc/5474769

31. Wehrli W. Rifampin: mechanisms of action and resistance [Internet]. Rev Infect Dis. 1983 [cited 2019Dec28]. Available from: https://pubmed.ncbi.nlm.nih.gov/6356275/

32. Velkov T, Roberts KD, Nation RL, Thompson PE, Li J. Pharmacology of polymyxins: new insights into an 'old' class of antibiotics [Internet]. Future Microbiol. 2013 [cited 2019Dec28]. Available from: https://pubmed.ncbi.nlm.nih.gov/23701329/

33. Bolard J, Joly V, Yeni P. Mechanism of Action of Amphotericin B at the Cellular Level. Its Modulation by Delivery Systems [Internet]. Journal of Liposome Research. 2003 [cited 2019Dec28]. Available from: https://www.tandfonline.com/doi/abs/10.3109/08982109309150728

34. Noor A, Preuss CV. Antifungal Membrane Function Inhibitors (Amphotericin B) [Internet]. StatPearl. 2019 [cited 2019Dec28]. Available from: https://europepmc.org/article/med/29493952

35. Quinn M, Fannin JT, Sciasci J, Bragg A, Campbell PK, Carias D, Crews KR, Gregornik D, Jeha S, Maron G, Pauley JL, Swanson HD, Wolf J, Greene W. Pentamidine for Prophylaxis against Pneumocystis jirovecii Pneumonia in Pediatric Oncology Patients Receiving Immunosuppressive Chemotherapy [Internet]. Antimicrobial Agents and Chemotherapy. 2018 [cited 2019Dec28]. Available from: https://www.ncbi.nlm.nih.gov/pmc/articles/PMC6105857/

36. Olson JM, Shah NA. Microtubule Assembly Inhibitors (Griseofulvin) [Internet]. In: StatPearls. 2019 [cited 2019Dec28]. Available from: https://europepmc.org/article/med/30726008

37. Zhu JD, Meng W, Wang XJ, Wang HC. Broad-spectrum antiviral agents [Internet]. Front Microbiol. 2015 [cited 2019Dec28]. Available from: https://pubmed.ncbi.nlm.nih.gov/26052325/

38. Razonable RR. Antiviral drugs for viruses other than human immunodeficiency virus [Internet]. Mayo Clin Proc. 2011 [cited 2019Dec28]. Available from: https://pubmed.ncbi.nlm.nih.gov/21964179/

39. Davies BE. Pharmacokinetics of oseltamivir: an oral antiviral for the treatment and prophylaxis of influenza in diverse populations [Internet]. J Antimicrob Chemother. 2010 [cited 2019Dec28]. Available from: https://pubmed.ncbi.nlm.nih.gov/20215135/

40. Patick AK, Potts KE. Protease inhibitors as antiviral agents [In- ternet]. Clin Microbiol Rev. 1998 [cited 2019Dec28]. Available from: https://pubmed.ncbi.nlm.nih.gov/9767059/

41. Anderson J, Schiffer C, Lee SK, Swanstrom R. Viral protease inhibitors [Internet]. Handb Exp Pharmacol. 2009 [cited 2019Dec28]. Available from: https://pubmed.ncbi.nlm.nih.gov/19048198/

42. Arvin A, Campadelli-Fiume G, Mocarski E, Moore PS, Roizman B, Whitley R, Yamanishi K. Human Herpesviruses: Biology, Therapy, and Immunoprophylaxis. Cambridge: Cambridge University Press; 20072007 [cited 2019Dec28]. Available from: https://pubmed.ncbi.nlm.nih.gov/21348071/

43. Andrei G, Topalis D, De Schutter T, Snoeck R. Insights into the mechanism of action of cidofovir and other acyclic nucleoside phosphonates against polyoma- and papillomaviruses and non-viral induced neoplasia [Internet]. Antiviral Res. 2015 [cited 2019Dec30]. Available from: https://www.semanticscholar.org/paper/Insightsinto-the-mechanism-of-action-of-cidofovir-AndreiTopalis/256aa0e9cd8c275c8d564eb962868f30f7fa23fa

44. Gitto S, Gamal N, Andreone P. NS5A inhibitors for the treatment of hepatitis $C$ infection [Internet]. J Viral Hepat. 2017 [cited 2019Dec30]. Available from: https://pubmed.ncbi.nlm.nih.gov/27925362/

45. Perry CM, Balfour JA. Fomivirsen. Drugs [Internet]. 1999 [cited 2019Dec30]. Available from: https://pubmed.ncbi.nlm.nih.gov/10193689/

46. Di Bisceglie AM, Martin P, Kassianides C, Lisker-Melman M, Murray L, Waggoner J, Goodman Z, Banks SM, Hoofnagle JH. Recombinant interferon alfa therapy for chronic hepatitis C. A randomized, double-blind, placebo-controlled trial [Internet]. N Engl J Med. 1989 [cited 2019Dec30]. Available from: https://europepmc.org/article/med/2509917

47. Hare S, Vos AM, Clayton RF, Thuring JW, Cummings MD, Cherepanov P. Molecular mechanisms of retroviral integrase inhibition and the evolution of viral resistance [Internet]. Proc Natl Acad Sci U S A. 2010 [cited 2019Dec30]. Available from: https://pubmed.ncbi.nlm.nih.gov/21030679/

48. Powers JH. Antimicrobial drug development - the past, the present, and the future [Internet]. Clin Microbiol Infect. 2004 [cited 2019Dec30]. Available from: https://pubmed.ncbi.nlm.nih.gov/15522037/

49. Packer S, Berman SA. Serotonin syndrome precipitated by the monoamine oxidase inhibitor linezolid [Internet]. Am J Psychiatry. 2007 [cited 2019Dec30]. Available from: https://pubmed.ncbi.nlm.nih.gov/18433663/

50. Grinde B. Herpesviruses: latency and reactivation - viral strategies and host response [Internet]. J Oral Microbiol. 2013 [cited 2019Dec30]. Available from: https://www.ncbi.nlm.nih.gov/pmc/articles/PMC3809354/

51. Sehrawat S, Kumar D, Rouse BT. Herpesviruses: Harmonious Pathogens but Relevant Cofactors in Other Diseases? [Internet] Front Cell Infect Microbiol. 2018 [cited 2019Dec30]. Available from: https://www.ncbi.nlm.nih.gov/pmc/articles/PMC5981231/ 
52. Karnsakul W, Schwarz KB. Hepatitis B and C [Internet]. Pediatr Clin North Am. 2017 [cited 2019Dec30]. Available from: https://pubmed.ncbi.nlm.nih.gov/28502443/

53. Hønge B, Jespersen S, Medina C, Té D, da Silva Z, Ostergaard L, Laursen A, Wejse C, Krarup H, Erikstrup C. Hepatitis $B$ virus surface antigen and anti-hepatitis $C$ virus rapid tests underestimate hepatitis prevalence among HIV-infected patients [Internet]. HIV Med. 2014 [cited 2019Dec30]. Available from: https://europepmc.org/article/med/24717010

54. Bouvier NM, Palese P. The biology of influenza viruses [Internet]. Vaccine. 2008 [cited 2019Dec30]. Available from: https://pubmed.ncbi.nlm.nih.gov/19230160/ 55. Singh S, Casubhoy I, Frankow J, Chronwall B. (2018). Influenza: How to Prevent the Next Pandemic [Internet]. 2018 [cited 2019Dec30]. Available from: 10.13140/RG.2.2.20847.79522.

56. Naif HM. Pathogenesis of HIV Infection [Internet]. Infect Dis Rep. 2013 [cited 2019Dec30]. Available from: https://www.ncbi.nlm.nih.gov/pmc/articles/PMC3892619/

57. Burke DS. Recombination in HIV: an important viral evolutionary strategy [Internet]. Emerg Infect Dis. 1997 [cited 2019Dec30]. Available from: https://pubmed.ncbi.nlm.nih.gov/9284369/

58. Singh S, Day A, Ganesan V, Shah S, Kim G, Moon J, Feldman K, Goldman J. (2019). Seroprevalence and Risk Factors of the Herpes Simplex Virus family: A Nationwide Sample Study [Internet]. [cited 2019Dec30]. Available from: 10.13140/RG.2.2.17492.35203.

59. Zhanel GG, Karlowsky JA, Rubinstein E, Hoban DJ. Tigecycline: a novel glycylcycline antibiotic [Internet]. Expert Rev Anti Infect Ther. 2006 [cited 2019Dec30]. Available from: https://pubmed.ncbi.nlm.nih.gov/16441206/

60. Fredrick K, Ibba M. Protein synthesis: Errors rectified in retrospect [Internet]. Nature. 2009 [cited 2019Dec30]. Available from: https://europepmc.org/article/med/19129838

61. Duke T, Michael A, Mokela D, et al. Chloramphenicol or ceftriaxone, or both, as treatment for meningitis in developing countries? [Internet]. Archives of Disease in Childhood 2003 [cited 2019Dec30]. Available from: https://www.ncbi.nlm.nih.gov/pmc/articles/PMC1763115/

62. Kapoor G, Saigal S, Elongavan A. Action and resistance mechanisms of antibiotics: A guide for clinicians [Internet]. J Anaesthesiol Clin Pharmacol. 2017 [cited 2019Dec30]. Available from: https://pubmed.ncbi.nlm.nih.gov/29109626/

63. Le T, Bhushan V, Sochat M, Chavda Y, Zureick A, Kalani M, Kallianos, K.First Aid for USMLE STEP 12019 [Internet]. MCGRAW-HILL EDUCATION. 2018 [cited 2019Dec30]. Available from:

64. Coronavirus disease 2019 (COVID-19) in the U.S. Atlanta [Internet]. Centers for Disease Control and Prevention, February 26, 2020 [cited 2020Mar2020]. Available from: https://www.cdc.gov/coronavirus/2019-ncov/cases-in-us.html

65. Munita JM, Arias CA. Mechanisms of Antibiotic Resistance [Internet]. Microbiol Spectr. 2016 [cited 2019Dec30]. Available from: https://pubmed.ncbi.nlm.nih.gov/27227291/ 66. Colson P, Rolain JM, Lagier JC, Brouqui P, Raoult D. Chloroquine and hydroxychloroquine as available weapons to fight COVID-19 [Internet]. Int J Antimicrob Agents. 2020 [cited 2020Mar13]. Available from: https://pubmed.ncbi.nlm.nih.gov/32145363/

67. Hoffmann M, Kleine-Weber H, Schroeder S, Krüger N, Herrler T, Erichsen S, Schiergens TS, Herrler G, Wu NH, Nitsche A, Müller MA, Drosten C, Pöhlmann S. SARS-CoV-2 Cell Entry Depends on ACE2 and TMPRSS2 and Is Blocked by a Clinically Proven Protease Inhibitor. Cell [Internet]. 2020 [cited 20200ct30]. Available from: https://pubmed.ncbi.nlm.nih.gov/32142651/ 68. Chen CT, Ng KJ, Lin Y, Kao MC. Red man syndrome following the use of vancomycinloaded bone cement in the primary total knee replacement: A case report [Internet]. Medicine (Baltimore). 2018 [cited 2019Dec30]. Available from: https://pubmed.ncbi.nlm.nih.gov/30572442/

69. Park H, Youk J, Shin DY, Hong J, Kim I, Kim NJ, Lee JO, Bang SM, Yoon SS, Park WB, Koh Y. Micafungin prophylaxis for acute leukemia patients undergoing induction chemotherapy [Internet]. BMC Cancer. 2019 [cited 2019Dec31]. Available from: https://bmccancer.biomedcentral.com/articles/10.1186/s12885019-5557-9

70. Craft AW, Brocklebank JT, Hey EN, Jackson RH. The 'grey toddler'. Chloramphenicol toxicity [Internet]. Arch Dis Child. 1974 [cited 2019Dec31]. Available from: https://www.ncbi.nlm.nih.gov/pmc/articles/PMC1549666/

71. Hilgenfeldt EG, Schlachterman A, Firpi RJ. Hepatitis C: Treatment of difficult to treat patients [Internet]. World J Hepatol. 2015 [cited 2019Dec29]. Available from: https://www.ncbi.nlm.nih.gov/pmc/articles/PMC4517154/

72. Santos KB, Souza RS, Atalla A, Hallack-Neto AE. Herpes zoster after autologous hematopoietic stem cell transplantation [Internet]. Rev Bras Hematol Hemoter. 2016 [cited 2019Dec30]. Available from: https://pubmed.ncbi.nlm.nih.gov/27863756/

73. Hayden FG, Sugaya N, Hirotsu N, et al. Baloxavir Marboxil for Uncomplicated Influenza in Adults and Adolescents [Internet]. N Engl J Med. 2018 [cited 2019Dec30]. Available from: https://pubmed.ncbi.nlm.nih.gov/301844nbgv 55/ 